\title{
Speech, Language and Hearing Science at the Federal University of Bahia: a historical approach
}

\author{
Melissa Catrini ${ }^{1}$ \\ https://orcid.org/0000-0002-2947-3157 \\ Yukari Figueroa Mise $^{2}$ \\ https://orcid.org/0000-0002-5273-1548

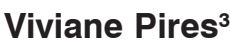 \\ https://orcid.org/0000-0002-2163-9191
}

Universidade Federal da Bahia - UFBA, Instituto de Ciências da Saúde, Departamento de Fonoaudiologia, Salvador, Bahia, Brasil.

2 Universidade Federal da Bahia UFBA, Instituto de Saúde Salvador, Departamento de Saúde Coletiva I, Salvador, Bahia, Brasil.

${ }^{3}$ Universidade Estadual de Ciências da Saúde de Alagoas - UNCISAL, Programa de Residência Multiprofissional em Saúde da Família, Maceió, Alagoas, Brasil.

Conflict of interests: Nonexistent

\section{(c) (i)}

Received on: March 26, 2019 Accepted on: July 1, 2019

Corresponding address:

Melissa Catrini

Avenida Reitor Miguel Calmon s/n.

Vale do Canela

CEP: 40110-902 - Salvador, Bahia, Brasil,

E-mail: melissa.catrini@ufba.br

\section{ABSTRACT}

Purpose: to investigate, from a historical perspective, the path that led to the creation of the Speech-Language Pathology and Audiology Undergraduate Program of the Federal University of Bahia.

Methods: this qualitative, cross-sectional study adopts an oral history methodology, using document analysis and interviews.

Results: a narrative was developed, bringing to light the history of this program and pointing to specificities that involve the training in Speech-Language Pathology and Audiology offered by UFBA. It also highlights the collaboration given by the student activist movement to these accomplishments.

Conclusion: the results of this research comprise a memory that can contribute to an in-depth reflection of the training in Speech-Language Pathology and Audiology in Brazil, making evident, in the process, the inseparability between educational and health demands.

Keywords: Speech, Language and Hearing Sciences; History; Education; Curriculum 


\section{INTRODUCTION}

In Brazil, the practice of speech-language pathology and audiology had begun a long time before being academically institutionalized and officially recognized. It may be confidently asserted that Brazilian speechlanguage pathology and audiology has its origins rooted in a specific sociopolitical and historical context, in which the social role of its forerunners is made evident in a scenario of criticism and aversion to sociocultural and economical diversity resulting from the country's industrialization process.

At the end of the 1920's and beginning of the 1930 's, large migratory groups of workers from different regions of Brazil and from different nationalities moved to the urban centers, particularly São Paulo, seeking for employment. These workers naturally grouped together according to their customs, language, interests and needs. The cultural heterogeneity even had an impact on the country's mother tongue. This new social structure imposed itself on the urban space and was interpreted by the official discourse as a threat to national identity and, consequently, its unity ${ }^{1,2}$. Actually, the "differences in morals, values, behavior, represented a kind of social pathology"2.

It's possible to state that the presence of such migrant workers resulted in modifications in the social organization of the time, causing some segments of society to become discontented and fearful, including the government ${ }^{1}$. Thus, the nationalist movement arose, whose agenda had as its main objective the social control and reorganization in favor of the longed-for national unity. Specialists and intellectuals from different fields of study (education, arts, health, etc.) engaged in the agenda proposed by the nationalist movement, hence actions were planned and executed, supported and backed by the State. Standardizing the mother tongue was one of the means used in the attempt to wipe the heterogeneity of these social manifestations; many historic events took place with this purpose, of which the First Congress of the National Language as Sung (I CLNC, as abbreviated in Portuguese) - held in 1937, in the city of São Paulo -, an event of great importance for the establishment of speech-language pathology and audiology in that scenario.

Organized by Mário de Andrade (who was then director of the Culture Department, supported by the Secretary of Education and Public Health of the City of São Paulo), the I CLNC had as its central theme "to fight the impurities of our language in artistic manifestations"2. It was then presented the work "Vices and defects in children's speech in Playgrounds", in which deviation of speech in children is registered for the first time, pointing to the need of intervention by a specialized professional with a reeducative approach. It must be noted that "Playground" was the name given to areas created by São Paulo City Hall to assist poor children, where medical and dental care was offered, along with pedagogical activities aimed at sanitary awareness, development of hygiene habits, moral values, among others. In the abovementioned work, it was also advocated the existence of orthophony centers with the purpose of correcting vicious pronunciation and speech problems, such as there had already been in the USA and Europe ${ }^{2,3}$.

It's important to call attention to the fact that the demands brought up in the I CLNC culminated in actions which, with time, led to the medicalization (or it should be said "therapeutization") ${ }^{2}$ of different social demands. One of such actions was the establishment, ten years later, of the Phonetic and Acoustic Laboratory (LFA, as abbreviated in Portuguese), linked to the Secretary of Education and Culture of the City of São Paulo. The LFA was the place where teachers with basic training started to work as orthophonists, correcting the speech of public school students, thus becoming the precursors in outlining the clinical profile of speechlanguage pathologists and audiologists. It should be emphasized that, at the time, these teachers specialization for speech reeducation involved the confluence of a medical perspective regarding the relation between normality and pathology, and the pedagogical point of view molded by the New School movement.

Only in the 1960's, the existing speech-language pathology and audiology practices were legitimated through university programs, initially offered as associate degrees ${ }^{4}$. The first program in the North/ Northeast region came into existence at the same time when the Federal Education Council changed the training programs, which were associate degrees, to "Full Bachelor Degree Speech-Language Pathology and Audiology Programs", enlarging the minimum curriculum from 1800 hours to 2700 hours. The recognition of the first program in the region (1983, at the Pernambuco Catholic University) happened at the same time when the Federal Speech-Language Pathology and Audiology Council (CFFa, as abbreviated in Portuguese) began its activities, which culminated in the approval of the first code of ethics for these professionals in 1984. 
It must be said that, nowadays, the national curriculum guidelines which set the outlines for speech-language pathology and audiology university programs are undergoing changes. In more recent times, the field has been noticeably shifting towards a critical positioning in face of social inequalities, and it has been promoting discussions on the formative processes for developing abilities which would furnish, along with technical knowledge, political, ethical and social awareness. In this regard, it is believed that a critical look into the past may substantially contribute in this process of building new principles and procedures for training speech-language pathologists and audiologists.

The aim of this study is to present, from a historical approach, the path that led to the creation of a SpeechLanguage Pathology and Audiology Program in a Brazilian public university. It intends to identify the main happenings and actors involved in developing the program, introducing the historical context in which it took place.

\section{METHODS}

This project held ethical research aspects in high regard, and it took place through the presenting and signing of an Informed Consent. The project was submitted to the Ethics Committee of the Public Health Institute of the Federal University of Bahia, in compliance with the CNS Resolution number 466, from December $12^{\text {th }}, 2012$; it was thus approved under the number 000389/2018.

For this study, the spatial profile was delimited to investigating the history of Speech-Language Pathology and Audiology in Bahia and at the Federal University of Bahia, permeated by the national context. The state of Bahia is taken as the referential, given that, in spite of the history of speech-language pathology and audiology in this region having followed the national movements of actions and interventions in public health in the 1950's and 1960's, the first programs were only opened in 1999. This long time separating the beginning of practices and the formalized training, as well as the period of over 10 (ten) years between the first program in the Northeast region (1983) and the opening of undergraduate programs in Bahia (1999), raise questions as to the reasons and the historical contexts involving the founding of Speech-Language Pathology and Audiology in the state and its effects on the way the profession presents and sustains itself at the present time.
For the temporal profile, it was thought at first of choosing the time post-academia, which starts with the beginnings of Speech-Language Pathology and Audiology in Brazil, in the 1960's. However, throughout the development of the project, it was decided to broaden the period and include the first acquirements resulting from the relation between Speech-Language Pathology and Audiology, Otorhinolaryngology and Education, which may identified from as far as the 1930's. The data acquired stretched progressively until 2017, so that, though briefly, it was possible to point out the historical landmarks in the advances in the field in Bahia during this period. Concerning specifically the Speech-Language Pathology and Audiology program at the Federal University of Bahia, the time profile encompasses the period between 1993 and 2017.

As for the sources, oral and written data were used. For the oral sources, oral history methodology was applied, by which the priority was interviewing people who could give testimony of their participation in the history of Speech-Language Pathology and Audiology in Bahia and at the Federal University of Bahia. For the selection of the interviewees, at first the snowball sampling methodology was used ${ }^{5}$. Then, the selection followed these criteria for choosing the testimonies: a) being a pioneer or protagonist in the field; b) testimonies that included, as much as possible, a specific period of this history, or of remarkable happenings, in order to map the time under study. Finally, for the analysis, 5 testimonies were selected from participants who: a) contributed for the founding of the program; b) were professors and/or; c) participated in organs/ institutions in the field. Each testimony was recorded, transcribed and transcreated ${ }^{6}$.

In addition to oral testimonies, other data sources used for this study were: written documents, visits to the archives of the joint board, the students' representative council and the congregation of the institution where the Speech-Language Pathology and Audiology program is maintained at the Federal University of Bahia and, especially, works whose theme was related to the History of Speech-Language Pathology and Audiology in Brazil, in Bahia and at the Federal University of Bahia; these were chosen for their representativity of the historical period studied. The search for these references also prioritized knowing the historical facts and political movements by means of ordinances and regulatory norms.

Once set the spatial and temporal profiles and the sources, it was possible to establish a documental 
corpus, which was descriptively-analytically interpreted. Since different types of sources, analyses and manners of presenting the results were used, the main methodology may be named as plural approach, which coordinates different possibilities of configurations in the field of historiography.

In general terms, the result analysis process was organized as follows: each testimony and written source selected was analyzed separately and together, inter-related with the documental corpus. The analyses and the discussion of the results include two stages: (a) documental analysis (non-oral sources) and (b) oral registry analysis ${ }^{6,7}$. After the stages (a) and (b) of interpretation of elements gathered from the documental corpus, it was sought to collect these fragments in a descriptive-analytical narrative so that the testimonies and the written sources were articulated (triangulation).

It's important to highlight that the interviewed subjects authorized their names to be exposed as the results and discussion were presented in this study.

\section{RESULTS}

Given that this study approaches the methodological ways of historiography ${ }^{8,9}$, the results of this investigation are presented in the format of a descriptive-analytical narrative, in which the theoretical, temporal and social dimensions of the founding history of the SpeechLanguage Pathology and Audiology program at the Federal University of Bahia.

\section{The Speech-Language Pathology and Audiology Program at the Federal University of Bahia}

The Federal University of Bahia (UFBA, as abbreviated in Portuguese) has 1808 as its initial landmark, when the School of Surgery of Bahia was founded. Beginning in 1946, under the leadership of Professor Dr. Edgar Santos, the federalization and integration of the isolated schools of higher education took place, starting the process of opening other programs at the University. Speech-Language Pathology and Audiology in this context was a very recent achievement in this University, since the first 30 seats in the program were opened only in 1999.

The Speech-Language Pathology and Audiology program at UFBA had its proposal linked to the interest of the Health Sciences Institute (ICS, as abbreviated in Portuguese) of hosting an undergraduate program. Before the implementation of the program, the ICS only offered courses for programs hosted by other units. As registered on official documents that present the first pedagogical project of the undergraduate SpeechLanguage Pathology and Audiology program at UFBA, in a meeting held on October $15^{\text {th }}, 1993$, the Department Council of the Health Sciences Institute approved the creation of a commission, constituted by the professors: MARIA AUGUSTA MORAES NASCIMENTO, of the Bioregulation Sciences Department, WALDECI LOPES BRAGANÇA, of the Biomorphology Sciences Department, GILDO RAMOS PIMENTEL, of the Biofunction Sciences Department, JEFFERSON IVAN CORRÊA, of the Bioaggression Sciences Department; by the Higher Education Technical employees: GRACE MARIA SAMPAIO (Biologist), MARIALDA SANTOS ROTONDANO (Educational Issues Technician); and by the speech-language pathologist and audiologists: LEONORA BASTOS DA SILVA, SILVIA FERRITE GUIMARÃES, CLÁUDIA C. LOPES and MARIA CECÍLIA CASTELO S. PEREIRA, representatives of the Center for the Association of Speech-Language Pathologists and Audiologists of Bahia, to proceed with studies aiming at developing a pre-project for the founding of the Speech-Language Pathology and Audiology program, in undergraduate level, at the Federal University of Bahia.

According to Silvia Ferrite (through oral communication), in face of the lack of opportunities to receive graduation level training in Speech-Language Pathology and Audiology at the time, and with the "objective of [...] preparing local speech-language pathologist and audiologist for working as professors" ${ }^{10}$, one of the first actions of this commission was to develop and put into practice the first specialization courses of the state in this field (in Audiology and Language). This opportunity was a landmark in Speech-Language Pathology and Audiology in Bahia (1995-1997), with the participation of much of the active speech-language pathologists and audiologists in Salvador and in the interior. Ana Paula Corona, Célia Regina Thomé and Silvia Ferrite - professors at the Speech-Language Pathology and Audiology program at UFBA until the present day took part in these specialization courses.

It is important to mention that Claudia Lopes and Maria Cecília Castelo Pereira, members of the abovementioned committee, are currently professors of the Speech-Language Pathology and Audiology program at the Bahia State University, and Leonora Bastos was one of the first speech-language pathologists and audiologists to work in Salvador. Silvia Ferrite, in her turn, was the first speech-language pathologist and 
audiologist of the Edgar Santos University Hospital (HUPES, as abbreviated in Portuguese); she was hired in 1995 and allocated at the Otorhinolaryngology Outpatient Center. Along the first seven years of work at the UFBA, Ferrite implemented and organized the Clinical Audiology Service of this outpatient center. In addition, implemented an improvement internship program in the field for speech-language pathologists and audiologists (the first to be offered in Salvador) and participated in the training of the residents in Otorhinolaryngology as preceptor.

As previously mentioned, the Speech-Language Pathology and Audiology undergraduate program pre-project at UFBA was approved in 1995 and enabled the strengthening of the ICS as a training institute, besides opening a place for training that faced the great need for speech-language pathologists and audiologists and the resulting difficulty of the population to have access to the cares offered by this professionals in the city of Salvador and in the state of Bahia. Initially, the faculty of the Speech-Language Pathology and Audiology undergraduate program was composed of temporarily hired professors. That was the case of Silvia Ferrite, Ana Paula Corona, Célia Regina Thomé and Desirée De Vit Begrow. Only in 2002, the first permanent professors with exclusive dedication were hired and, in 2003, the first class graduated, the same year in which the program was recognized by the Brazilian Ministry of Education (recognition renewed in 2007, 2011 and 2015). Regarding the initial period of the program, Silvia Ferrite, in oral communication, highlights that:

"(...) with a reduced faculty (due to difficulties obtaining openings through public tendering), the Speech-Language Pathology and Audiology Department remained some years among the first ones in the assessment of faculty work overload, according to a systematic evaluation conducted by the UFBA at the time, called 'profile'. The first exclusively dedicated professors took on up to 20 weekly hours of teaching in order to maintain the program in accordance with obligatory curriculum, and most of the professors at the Speech-Language Pathology and Audiology Department were temporarily hired".

In the words of Desirée De Vit Begrow (information provided in an interview): "in the beginning, the program was upheld by the work of a few people, who invested and donated much of their life for its growth".
The Speech-Language Pathology and Audiology Department was founded on the second semester of 2002, same year in which the Speech-Language Pathology and Audiology Faculty Assistance Center - CEDAF, as abbreviated in Portuguese - the clinicschool associated with the Department. Since there were no professors with the required academic degree to compose the board of directors of the Department, nor to coordinate the joint board, the professors Roberto Paulo Correia de Araújo and Maria Penha D'Oliveira Belém, of the ICS Biofunction Department (now, Biochemistry and Biophysics) and Biomorphology Department took on these offices, working very closely to the professors Silvia Ferrite, Ana Paula Corona and Ana Caline Nóbrega da Costa. Silvia Ferrite was the first Speech-Language Pathology and Audiology professor to be chairperson of its Department (Feb, 2003 - Mar, 2005).

The program's first syllabus had a total course load of 3780 hours, divided in elective, optional, complementary obligatory and minimum curricular courses, which had to be taken in no less than four years. Between 1999 and 2008, the Speech-Language Pathology and Audiology Joint Board proceeded with many adjustments with the purpose of optimizing the use of the available course load, in order to adapt the curriculum to the objectives proposed in the Pedagogical Project.

Beginning in 2002, with the approval of the National Education Council/ Higher Education Assembly for the National Curriculum Guidelines (DCNs, as abbreviated in Portuguese) for the Speech-Language Pathology and Audiology Undergraduate Programs ${ }^{11,12}$, changes were made in the profile of the speech-language pathology and audiology graduate. Following the establishment of these guidelines, training in Speech-Language Pathology and Audiology was be oriented by preparing professionals capable of working at the Unified Health System (SUS, as abbreviated in Portuguese from Unified Health System), offering quality, efficiency and determination. The DCNs also pointed to the search for many scenarios for the theoretical-practical training from the beginning of the program.

Another important point in this aspect was the association between the fields of education and health, which mobilized for creating inducing policies for training health professionals ${ }^{13}$. The Pro-Health (National Program for Reorientation of the Health Professional Training) and the PET-Health (Program for Health Education through Work) were the government's 
attempts at innovating health training based on theoretical concepts, teaching-learning methodologies, and teaching-health integration aiming at a "integral approach to the illness-health process with focus on basic care"13. The Speech-Language Pathology and Audiology program at UFBA took part in the notices related to Pro-Health and PET-Health. Pro-Health took place between 2007 and 2008; as for PET-Health and PET-Networks, several notices had the participation of Speech-Language Pathology and Audiology professors and students from UFBA, between 2012 and 2015.

Mobilized by the changes in health policies and health professionals training policies, in 2009 a new pedagogical project was proposed; the curricular reform was justified by the following points:

- Delimitation and incorporation of new fields of knowledge into Speech-Language Pathology and Audiology;

- Constant changes in emerging social demands;

- Lack of a practical curricular component in the field of Public Health, more specifically at the Basic Health Units (UBS, as abbreviated in Portuguese) (this was brought up in meetings of the SpeechLanguage Pathology and Audiology Department and Joint Board and ratified by the evaluators of the Ministry of Education and Culture, in 2013);

- Frailty of the curriculum in the discussion and deepening of theoretical-methodological assumptions for the training of a health professional committed to the social conditions;

- Need of redistributing the course load evenly between the seven great fields of work of the speech-language pathologist and audiologist, as recognized by the Federal Speech-Language Pathology and Audiology Council.

The proposal was approved in November, 2009 by the Teaching Academic Council of UFBA, substantially increasing the total course load from 3,735 hours to 4,588 hours, to be concluded in no less than 5 years.

The curricular reform undertaken in 2009 was efficient in terms of ensuring the inclusion of Public Health training courses in the program's curriculum, which was already present in the curricular guidelines for the Speech-Language Pathology and Audiology programs since 2002 and a demand brought about by the need of training purposefully thought on the Unified Health System, with more professionals being hired and speech-language pathology and audiology being inserted into various contexts of caregiving in the system. None other was in view in the training centers promoted by the partnership between the Ministry of Education and Culture and the Ministry of Health, between 2003 and 2008.

The reform was successful in regard to the greater distribution of course load between the different fields of knowledge related to the work in speech-language pathology and audiology and in the variety of activities in supervised internships and heterogeneous practices. However, the curricular structure continued to be molded by the logical division theory/practice, basic core/professionalizing core, culminating in areas of practice continuously set apart from theory and curricular components very specialized but little articulated with each other.

Considering the trajectories that led to transformation, since Pro-Health, along with the abovementioned issues, it's vital to highlight the change in the present profile of university students. The inclusion of the UFBA in the Unified Selection System (SISU, as abbreviated in Portuguese), i.e., in the computerized system of the Ministry of Education and Culture through which the university offers seats for those who take the High School National Exam (ENEM, as abbreviated in Portuguese), and the validity of the quota policies were responsible for the emergence of new training demands. There is great concern with the political and university context, once the training for the profession now involves the requirement of a curriculum including the ability to read the social demands as they meet the job routine. In other words, the current student body asks for such training that enables them to escape the little sustainable "fluctuating market tendencies".

\section{DISCUSSION}

The narrative presented above offers us a historical panorama of the founding of the Speech-Language Pathology and Audiology program at the UFBA. However, for a deeper analysis, it's necessary to highlight the historical context in which the program was created. In it, an intimate connection between the program and the history of speech-language pathology and audiology in the Brazilian Northeast is revealed.

As it happened in the country as a whole, in the Northeast the practice of speech-language pathology and audiology arrived before its institutionalization and the founding of undergraduate program. In the Northeast, the field of education triggered the demand for speech-language pathologists and audiologists, especially in relation to the politically and economically disadvantaged local population. It was common to think 
that the inability to learn resulted from disadvantageous life conditions of the poor portions of society, and their interest for education led to the acknowledgement that a great part of them had language problems ${ }^{14}$. Thus, literacy educators (from public schools) and health professionals, concerned with the situation, sought to find the causes of those language problems, which most of the time were either related to organic aspects or explained by the prejudice as to the poor families' children's ability to learn how to read and write.

In this sociopolitical and historical context, the state of Pernambuco was the first to ensure the formalization of speech-language pathology and audiology practices, when the first Speech-Language Pathology and Audiology undergraduate program of the North and Northeast regions was founded at the Pernambuco Catholic University (UNICAP, as abbreviated in Portuguese). This program received official recognition in 1983 and emerged as an expansion of the activities of the Speech-Language Pathology and Audiology service at the Psychology Clinic in that institution, with strong institutional support from the Pontifical Catholic University of São Paulo (PUCSP, as abbreviated in Portuguese) ${ }^{15}$.

As it has been mentioned in the introduction, the first program in the North/Northeast region was founded at the same time when the Federal Education Council changed the undergraduate programs, up until then associate degree level, into "Full Speech-Language Pathology and Audiology Bachelor Degree", and, in the same year when the activities of the Federal SpeechLanguage Pathology and Audiology Council (CFFa, as abbreviated in Portuguese) were initiated.

In Bahia, the narratives acquired through interviews with professionals who pioneered in this field in the state show that the search for speech-language pathology and audiology professionals and training was mobilized at first by the arrival of "external volunteer help" to the internal social programs ${ }^{16}$. This is what Eliete Leal de Araújo, known as Lia Mara, one of the pioneers in speech-language pathology and audiology in Bahia, highlights in her report ${ }^{17}$ :

"This work led 'Brother Dubois', director of the Psychology Institute of the Catholic University of Salvador, to invite me to work with language problems and also to participate in a specific course to be offered by a North American speech-language pathologist and audiologist, member of the Peace Corps, called Carol Perry".
On the other hand, as reported nationwide, the first speech-language pathology and audiology practices in Bahia also arose from demands of the public health/ education programs, in which teachers of the Secretary of Education of the State of Bahia received specialized training to care for children with speech difficulties, as it's revealed by the report by Sônia Veloso, another forerunner of Speech-Language Pathology and Audiology in the state ${ }^{17}$ :

"In the Secretary of Education there were Aldina and Andiva, who worked as speech therapists. [...] They were old-time teachers in the Secretary of Education who took the course offered by the National Institute for the Education of the Deaf and took care of children with special needs, as well as those who came by complaint of their schools".

A unique characteristic in the beginning of SpeechLanguage Pathology and Audiology in Bahia is related to the work done by the Brazilian Legion of Social Assistance (LBA, as abbreviated in Portuguese) Federal Institution of Social Assistance, founded in 1969 and integrated to the Ministry of Social Security and Social Assistance, in 1974. In the beginning of the 1980"s, LBA funded different institutions and social programs in Bahia. However, they required that, for the partnership to be established, a speech-language pathologist and audiologist should be a member of the technical staff. For this reason, professionals of other states were brought to work in rehabilitation clinics who kept a partnership with LBA in Salvador ${ }^{16}$.

Thus, it can be said that the speech-language pathology and audiology work in the capital of the state of Bahia had its origin deeply rooted in "importing" professionals to work with disabled people, in initiatives such as that of Pestalozzi Institute of Bahia, Rehabilitation Institute of Bahia, Dr. Pinto Duarte Cerebral Palsy Clinic, Association of Parents and Friends of Children with Learning Disability, among other institutes accredited by LBA $^{10,16}$. With time, the same movement took place in cities in the interior of the state, as Feira de Santana.

Between the decades of 1970 and 1980, the Center of Pro-Association of Speech-Language Pathologists and Audiologists of the State of Bahia composed by 18 of these professionals ${ }^{10}$. This association had its participation registered in the history of the national struggle for regulating the profession, actively participating with the Interstate Movement of the SpeechLanguage Pathology and Audiology Entities and the 
National Congress during this period. Besides, this center was strongly active in organizing the speechlanguage pathology and audiology working class in Bahia, promoting scientific events such as the I Speech-Language Pathology and Audiology Day of Bahia, in 1983; and hosting the II Brazilian SpeechLanguage Pathology and Audiology Congress, which took place in Salvador, Bahia, in 1986. In addition, they promoted courses in fields of interest in speechlanguage pathology and audiology, striving for professional improvement and theoretical framework aimed at practice, as the courses given by Elisabeth Teixeira, of the Vernacular Languages Department, Languages Institute, Federal University of Bahia.

As it can be seen, the governmental initiatives continued inconsistently, lacking long-term planning. Thus, the history of Speech-Language Pathology and Audiology in Bahia was characterized by private initiatives both in practice and training ${ }^{10}$. In this sense, the abovementioned center helped create professional identity for the speech-language pathologists and audiologists in the state, also helping to make this profession known in different places, striving for recognition in both the political and social aspects. To this testifies Leonora Bastos da Silva, a speech-language pathologist and audiologist who began her activities in Salvador, in $1976^{10}$ :

"In the administration of the mayor Lídice da Mata, we held a meeting with the Secretary of Health. [...] He asked us to survey the need for a speech-language pathologist and audiologist in all health centers in the city of Salvador. A communal work involving the other speech-language pathologists and audiologists was carried out. [...] The professor Maria Augusta Dantas do Nascimento, from the Health Sciences Institute of the Federal University of Bahia, visited us and spoke of the possibility of founding a Speech-Language Pathology and Audiology program".

Attention should be called to the fact that the Center of Pro-Association of Speech-Language Pathologists and Audiologists of the State of Bahia took part in developing the pre-project of the Speech-Language Pathology and Audiology Program of the Federal University of Bahia, approved in June $5^{\text {th }}, 1995$. In that year, the juridical person Professional Association of the Speech-Language Pathologists and Audiologists (APROFEB, as abbreviated in Portuguese) was founded ${ }^{17}$. Only in 1999, the first Speech-Language
Pathology and Audiology undergraduate class in Bahia was opened, at the UFBA and at the Bahia State University (UNEB, as abbreviated in Portuguese).

Another point to be called attention to, as the history of the Speech-Language Pathology and Audiology program at UFBA is analyzed, is the strong presence of the student activism in the changes the program went through, throughout these 20 years of existence.

Student activism refers to the constant restlessness and mobilization of students, either by changes of something granted or by the longing for something new regarding the different aspects of academic life and society. At UFBA, the Student Activism in SpeechLanguage Pathology and Audiology (MEFa, as abbreviated in Portuguese) had, and still has, a relevant role in the continuous buildup and development of the undergraduate Speech-Language Pathology and Audiology program. It should be emphasized that one of the distinguishing characteristics of the MEFa in this academic environment is the autonomy of the student body, which, in different occasions, acted independently of the Central Students' Representative Council and of the very Speech-Language Pathology and Audiology Students' Representative Council (DAFono, as abbreviated in Portuguese), even urging the latter to mobilize in face of an agenda considered important by the students.

The DAFono/UFBA was created in 2000 , i.e., in the year subsequent to the opening of the first class of the Speech-Language Pathology and Audiology program. It came into being as a tool created by the students with the purpose of making feasible both the discussion and the achievement of the students' agenda. Presently, the DAFono is perceived as a synthesis of the process of the students' organization and struggle in the SpeechLanguage Pathology and Audiology classes at UFBA, guided by the principles of autonomy and by the buildup of an organic relation between the students, and between them and the other participants in the broader educational and social scenario.

As previously said, the Speech-Language Pathology and Audiology program at the UFBA underwent many changes throughout its history and, in many of them, the organized students were present. It can be claimed that, in the context of the Speech-Language Pathology and Audiology undergraduate program, the students' participation makes it even more concrete the articulation between faculty, students administrative technician in the search for improvements for all. Indeed, the work of the DAFono/UFBA was noticeable 
in the political/social struggle within the program and the University as a whole, besides being present in the national panorama of the students' activism in SpeechLanguage Pathology and Audiology.

Throughout the years, the DAFono/UFBA acted on the autonomous organization of scientific events and in the mobilization of students for seeking their interests, achieving actual results in the municipal, state and national spheres. Evidences of this history are present in oral and written reports filed in the Students' Representative Council itself, since 2003. In that year, in the National Speech-Language Pathology and Audiology Students Meeting (ENEFON, as abbreviated in Portuguese), which took place in Paraíba, the DAFono worked along with other students' representative councils from Bahia and other states of the country in the development of the VER-SUS Project (which stands, in Portuguese, for Experiences and Internships in the Reality of the Unified Health System), promoted by the Ministry of Health in partnership with United Network, and whose focus is to train workers for the Unified Health System. Still in 2003, the DAFono cooperated in the campaign against the Medical Act, a bill aimed at regulating the doctor's job, which, at the time, had a dubious text regarding the autonomy of the remainder of the health professionals.

These events brought great bustle among the students' representative councils all over Brazil, leading to the founding of new students' representative councils, in changes concerning perspectives deemed as more "academicist" in the student activism, in the buildup of unified students' representative councils and in a series of modifications in the political and local university scenario.

In 2004, the DAFono/UFBA participated directly in the development of the ENEFON, meeting with the students' representative councils of the Bahia State University, the Federal University of São Paulo, the Pontifical Catholic University of São Paulo, the University of São Paulo and the Alagoas Health Sciences State University in the CONEFON (Portuguese acronym for Speech-Language Pathology and Audiology Students Entity National Council), which took place in the Federal University of Minas Gerais (UFMG). The ENEFON, at this time, was based at UFBA and had such a mobilizing political character that strengthened the establishment of a students' strike in the university, with great participation of the Speech-Language Pathology and Audiology students.
In 2005, the DAFono/UFBA, active in the management of the National Executive Board of the Speech-Language Pathology and Audiology Students (DENEFONO, as abbreviated in Portuguese), took part in the World Social Forum and the National Workshop for Assessing the VER-SUS, though soon after broke off with that proposal for they understood that the imposing of the rules presented there reduced the students' autonomy in the project's context. In that scenario, the DAFono/UFBA was a protagonist in the national movement against the university reform proposed by the REUNI (Portuguese acronym for Support Program to Restructure and Expand Federal Universities), instituted by the Decree number 6,096 , from April 24 2007.

In its turn, in 2006 the DAFono/UFBA hosted a CONEFON and participated in the buildup of the ENEFON to take place in Vitória, ES, and funded by the Ministry of Health. This ENEFON was the first to discuss the axis of the student activism, social movements, Health, Education and Science. According to Marcos Vinícius de Araújo and Vladimir Arce, both of them professors at the Speech-Language Pathology and Audiology Department at UFBA and members of the national MEFa in the 2000's, and the speech-language pathologists and audiologists Ana Carolina Gonçalves and Amanda Jarissa da Silva, graduated from UFBA, this Meeting was capable of "reigniting the flame" of the organized MEFa and of all speech-language pathology and audiology students in the country. At this time, there was also a greater strengthening of the struggle against REUNI.

The following years were characterized by many struggles, achievements and losses by the national MEFa. The intensity of the events was also noticeable at UFBA, where the DAFono was included in the Joint Board and in the Speech-Language Pathology and Audiology Department, which guaranteed their representative rights in these institutional contexts. There was also the conquest of their own physical space and the participation in the process of curricular adjustments with the presentation of the new way of thinking concerning training in Speech-Language Pathology and Audiology - a way which led to reflecting on social, ethno-cultural, political and scientific aspects.

In 2008, when REUNI was implemented, the wave of students' demonstrations was intensified, as rectories were occupied, strikes were put into effect and divergences between faculty and student body were made manifest. The DAFono took part in these demonstrations 
and published the REUNl's Gray Book ${ }^{18}$, a dossier complaining against the consequences of the project to the university. This book was divided in two volumes, including testimonies of people belonging to different undergraduate programs from the whole country. The book was addressed to the President of the Republic, Luís Inácio Lula da Silva, to the Minister of Education, Fernando Haddad, to the National Congress and to the Brazilian people. It should be pointed out that, though being an initiative of DAFono/UFBA, the DENEFONO had an essential role in gathering testimonies and spreading the proposal contrary to REUNI, as they visited different universities and organized the students' base in these environments.

As the Speech-Language Pathology and Audiology program at UFBA joined the REUNI, the students didn't stop mobilizing and claiming better teaching conditions. Indeed, their joining caused great impact, once the program doubled its size, making room for 60 students, 30 in each semester, though maintaining insufficient facilities and personnel to meet their own demand. Actually, there were changes in the human resources staff, as professors and speech-language pathology and audiology technicians were hired with dedication to the program, the course load stipulated by the current curriculum wasn't fully met.

From the MEFa's viewpoint, the arrival of REUNI had the side effect of splitting the movement nationwide. In this scenario, joint mobilizations with other programs at UFBA were directed to DAFono, having as its agenda the claim for more professors, facilities, mobility, accessibility, guaranteed scholarships for permanence at the university and other similar requests. In addition to this, the DAFono promoted internal and external debates with the participation of the whole academic community, getting involved in social agenda regarding ethno-racial, gender, sexual orientation, disabilities, educational, health and social movements' issues.

Nowadays, the national MEFa is undergoing a restructuring phase. The Movement aims to mobilize the buildup of National Meetings that would lead to reflections on the standing of the Speech-Language Pathology and Audiology student in the institutional environments, making opposition to any kind of oppression within the University and, specifically, in the professor-student relation. Internally, in 2016, the DAFono/UFBA participated in the Academic Health Forum at UFBA and in the initiatives to organize Regional Speech-Language Pathology and Audiology Students Meetings (EREFON, as abbreviated in
Portuguese). The participation of the DAFono in the faculty evaluation commission of the Speech-Language Pathology and Audiology Department was of great importance, as was their participation in the activities of the Structuring Faculty Center of the Speech-Language Pathology and Audiology undergraduate program, actively assisting in the reflections that sustain the steps in developing a new pedagogical project for the program.

\section{CONCLUSION}

The history of Speech-Language Pathology and Audiology in Brazil reflects the history of the struggle of professionals and students to gain space, autonomy and maturity in a profession that is active in different ways, in different situations of the human existence, seeking to assist the population's continuous health and well-being. In Bahia, the particularities of the process of the speech-language pathologist and audiologist professional buildup do not hide the strength of the collective struggle in defense of Speech-Language Pathology and Audiology. This strength is reflected in the history that supports the founding of the SpeechLanguage Pathology and Audiology program at the UFBA, and in the remarkable presence of the students activism in the consolidation of the program throughout the years, making evident the inseparability between educational and health demands in this process.

Currently, Speech-Language Pathology and Audiology faces the challenge of assessing the present scenario in the fields of health and education, obligating to step forward in the direction of better understanding and responding to the social demands regarding training and caregiving that keeps on pressing for changes. This is the movement which mobilizes professionals and entities in the field to think over the national curricular guidelines for undergraduate programs. In this respect, the present study may be referred to as an effort of historicizing which points to something beyond a mere historical registry. The result of this research compose a memory that may contribute to the improvement of the Speech-Language Pathology and Audiology undergraduate program at the UFBA; simultaneously, it is presented as groundwork for deeper reflections regarding the professional and citizen training of the speech-language pathologist and audiologist in the undergraduate program. 


\section{REFERENCES}

1. Berberian AP. Fonoaudiologia e educação: um encontro histórico. São Paulo: Ed. Plexus; 1995.

2. Oliveira F. Por uma terapêutica fonoaudiológica: os efeitos do discurso médico e do discurso pedagógico na constituição do discurso fonoaudiológico [dissertação]. Porto Alegre (RS): Universidade Federal do Rio de Grande do Sul; 2002.

3. Neto LHF. O Início da prática fonoaudiológica na cidade de São Paulo - seus determinantes históricos e sociais [Dissertação]. São Paulo (SP): Pontifícia Universidade Católica de São Paulo; 1988.

4. Aarão PCL, Pereira FCB, Seixas KL, Silva HG, Campos FR, Tavares APN et al. Histórico da Fonoaudiologia: relato de alguns estados. Rev Med Minas Gerais. 2011;21(2):238-44.

5. Vinuto J. A amostragem em bola de neve na pesquisa qualitativa: um debate em aberto. Temáticas. 2014;22(44):203-20.

6. Meihy JCSB. Manual de história oral. São Paulo: Loyola; 2000.

7. Pimentel A. O método de análise documental: seu uso numa pesquisa historiográfica. Cadernos de Pesquisa. 2001;114(1):179-95.

8. Kirschner TC. A reflexão conceitual na prática historiográfica. Textos de história. 2007;15(1/2):49-61.

9. Nobre SLP, Rojas LR, Gomes NS. Os princípios metodológicos para o fazer historiográfico segundo Koerner. Revista Philologus. 2017;23(69):1209-15.

10. Nunes RTD, Maia SM. Narrativas sobre o início das práticas fonoaudiológicas na cidade Salvador, Bahia, Brasil. Saúde Soc. 2013;22(3):962-71.

11. Nascimento R. Fonoaudiologia completa 30. Revista Comunicar. 2011;12(51):4-5.

12. BRASIL. Resolução CNE/CES 5, de 19 de Fevereiro de 2002. [cited 2019 March 26]. Available from: http://portal.mec.gov.br/cne/arquivos/pdf/ CES052002.pdf

13. Garcia VL, Di Ninno C. Diretrizes Curriculares Nacionais. In: Marchesan I, Silva J, Tomé M (eds). Tratado das especialidades em Fonoaudiologia. São Paulo: Roca, 2014. p. 1055-9.

14. De Nardi V. Cursos de graduação em Fonoaudiologia no estado da Bahia: formação acadêmico-profissional [Dissertação]. Salvador (BA): Universidade Federal da Bahia; 2010.
15. Didier MSL. Fonoaudiologia: sua história em Pernambuco [Dissertação]. São Paulo (SP): Pontifícia Universidade Católica de São Paulo; 2001.

16. Cardoso C, Titonel T. A fonoaudiologia na Bahia: uma história recente. Rev. baiana saúde pública. 2004;28(1):96-9.

17. Junior M. Pernambuco: porta de entrada da Fonoaudiologia no Norte/Nordeste. Comunicar. 2011;12(51):22-5.

18. DAFONO/UFBA: Diretório Acadêmico de Fonoaudiologia/Universidade Federal da Bahia. Livro Cinza do REUNI. Dossiê-denúncia das consequências do REUNI. 2008. [cited 2018 March 07]; Available from https://livrocinza.files. wordpress.com/2008/08/livro_cinza_do_reuni.pdf 